Leadership and Nursing 


\section{ESSENTIALS OF NURSING MANAGEMENT}

Titles in the series

Annabel Broome: Managing Change, 2nd edition

Principles of complex change

Leadership and creating change from within

Imposed to change

The nurse as a change agent

Identifying training and development needs

Appendices

June Girvin: Leadership and Nursing

The development of theories of leadership

Interpretations of leadership

Interpersonal skills and leadership

Leadership in nursing

The story so far...

Traditional attitudes and socialisation

Motivation

Leadership today

Vision - foresight, insight and dreams

Diana Sale: Quality Assurance, 2nd edition

An introduction to quality assurance

Total quality management

Standards of care

Clinical audit

Clinical protocols

Monitoring of providers by purchasers

Verena Tschudin with Jane Schober: Managing Yourself, 2nd edition

'Know theyself'

Valuing yourself

Motivating yourself

Asserting yourself

Stressing yourself

Supporting yourself

Celebrating yourself

Developing yourself and your career 
ESSENTIALS OF NURSING MANAGEMENT

\title{
Leadership and Nursing
}

\author{
June Girvin
}




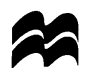

(C) June Girvin 1998

All rights reserved. No reproduction, copy or transmission of this publication may be made without written permission.

No paragraph of this publication may be reproduced, copied or transmitted save with written permission or in accordance with the provisions of the Copyright, Designs and Patents Act 1988 , or under the terms of any licence permitting limited copying issued by the Copyright Licensing Agency, 90 Tottenham Court Road, London W1P 9HE.

Any person who does any unauthorised act in relation to this publication may be liable to criminal prosecution and civil claims for damages.

The author has asserted her right to be identified as the author of this work in accordance with the Copyright, Designs and Patents Act 1988.

First published 1998 by

MACMILLAN PRESS LTD

Houndmills, Basingstoke, Hampshire RG21 6XS

and London

Companies and representatives

throughout the world

ISBN 978-0-333-72375-3

DOI 10.1007/978-1-349-14698-7

ISBN 978-1-349-14698-7 (eBook)

A catalogue record for this book is available from the British Library.

This book is printed on paper suitable for recycling and made from fully managed and sustained forest sources.

$\begin{array}{llllllllll}10 & 9 & 8 & 7 & 6 & 5 & 4 & 3 & 2 & 1\end{array}$

$\begin{array}{llllllllll}07 & 06 & 05 & 04 & 03 & 02 & 01 & 00 & 99 & 98\end{array}$

Editing and origination by Aardvark Editorial, Mendham, Suffolk 
For the members of PNF 1993-1996 


\section{Contents}

Acknowledgements

ix

Preface

$\mathrm{x}$

Introduction

Chapter 1 The Development of Theories of Leadership 5

Machiavelli (1469-1527) 6

Leader as Hero $\quad 8$

Weber's Three Bases 9

Power 12

Position Power 12

Knowledge Power 13

Personality Power and Charisma $\quad 14$

Power versus Leadership $\quad 16$

$\begin{array}{ll}\text { References } & 17\end{array}$

$\begin{array}{lll}\text { Chapter } 2 & \text { Interpretations of Leadership } & 18\end{array}$

Leadership as a Personal Quality 18

Leadership as a Behavioural Style 22

Leadership as a Contingency Approach $\quad 25$

References $\quad 27$

Chapter 3 Interpersonal Skills and Leadership 29

Leadership and Relationships 29

Organisational Culture $\quad 30$

Groups and Group Relationships 33

Facilitator versus Leader? $\quad 34$

Putting it Together 35

References 36

Summary and Conclusion to Chapters $1-3 \quad 37$

References 38

Further Reading on Group Work $\quad 39$ 


\section{Contents}

$\begin{array}{lll}\text { Chapter } 4 & \text { Leadership in Nursing } & 40\end{array}$

History and Politics $\quad 41$

Florence Nightingale $\quad 42$

Carry On, Matron? 43

Salmon: the 1960s and 70s 44

Griffiths and Groping in the Dark 46

Stopping the Rot 49

References 51

Chapter 5 The Story So Far... 54

Transformational Leadership $\quad 58$

References $\quad 65$

Further Reading $\quad 66$

$\begin{array}{lll}\text { Chapter } 6 & \text { Traditional Attitudes and Socialisation } & 67\end{array}$

Women's Work 71

What Do We Need To Do? 73

What Are We Doing To Encourage Leaders? $\quad 74$

References $\quad 76$

Additional Information $\quad 77$

$\begin{array}{lll}\text { Chapter } 7 & \text { Motivation } & 78\end{array}$

Maslow and Herzberg 79

Vroom $\quad 81$

References $\quad 85$

Chapter 8 Leadership Today $\quad 88$

Having and Achieving Goals $\quad 90$

Initiating and Implementing Change $\quad 90$

Having and Using Influence $\quad 91$

Having and Using Power $\quad 92$

Mentoring 92

Taking Responsibility for the Growth of Self and Others 93

Forging and Sustaining Relationships 94

Having and Articulating a Vision 95

References 95

Further Reading $\quad 96$ 


\section{Leadership and Nursing}

Chapter 9 Vision - Foresight, Insight and Dreams $\quad 97$

Step One - Information-gathering $\quad 98$

Step Two - Involve Others 99

Step Three - Check It Out 99

Step Four - Tweakability $\quad 100$

'The Trouble with Visions... 100

Making it Happen 101

Summary 104

References $\quad 105$

Further Reading $\quad 105$

$\begin{array}{ll}\text { Afterword } & 106\end{array}$

$\begin{array}{ll}\text { Index } & 108\end{array}$ 


\section{Acknowledgements}

There are many people who have been instrumental in the development and formation of this book, those mentioned below having made a particular contribution.

Special thanks go to Mary Monnington, who has proved to be a friend indeed. She also makes me laugh, which has been an especially useful talent over the past 2 years! Thanks also go to Professor Steven West of the University of the West of England who has been generous with his time and his advice, and who eased the pressures on me at just the right moments. I am truly grateful to you both.

Thanks are due to Steph Keeble and Liz Tregoing for reading and commenting on the early drafts - especially to Liz for the hospitality enjoyed in her beautiful Cotswold garden and for the many sensible suggestions that she made for improving the text. I would also like to thank my husband, Adrian, who is always there, whatever happens. 


\section{Preface}

This book has been written during what can at best be described as a challenging period in my career, but a period in which I have learned much about leadership. Writing it has helped me to make sense of many experiences - not just recent ones, but also ones from throughout my career - and I hope that it will also help the reader to see things a little more clearly. Good leadership is a beacon in a murky world. It can make even the most difficult of circumstances exciting and stimulating to work through. Good leaders should be nurtured, supported and recognised for the major contribution they can make to working lives. Poor leadership not only stunts organisations, but can also leave the people working in those organisations angry, frustrated and bewildered.

Sadly, our tolerance of ineffective leadership seems endless, particularly where it occurs outside our own profession. We have been, and still are, quick to criticise nurse leaders who do not meet our expectations, but it is harder to be openly critical of the hand that feeds us - the manager and the employer. Recognising poor leadership is the first step towards improving it. This book is written to help nurses to understand nursing leadership and the factors that have influenced its development over the years, but I hope that it may also enable the reader to recognise good and not so good leadership, whatever the background of the leader. I hope that it helps readers to choose their role models carefully and develop their own skills effectively.

In an ideal world, I would dearly like to see a clinical qualification become essential for any senior, influential management position. Clinicians are best placed to manage and lead the service; they do, after all, know it best. Far too few nurses aspire to chief executive positions, and even fewer actually reach them. Nursing is not a support service, but it is a hard struggle ensuring that it is not treated like one. So, learn to lead - then get out there and turn the boardroom tables over. 